\title{
New records of Ophiuroidea (Echinodermata) from the coast of Chiapas, Mexico
}

\author{
Nuevos registros de Ophiuroidea (Echinodermata) de la costa de Chiapas, México
}

\author{
Rebeca Granja-Fernández ${ }^{1}$, Pedro Diego Rangel-Solís², María Dinorah Herrero-Pérezrul ${ }^{3}$ and Andrés López-Pérez ${ }^{4}$
}

'Doctorado en Ciencias Biológicas y de la Salud. Universidad Autónoma Metropolitana. San Rafael Atlixco 186, Col. Vicentina. 09340. CDMX. México ${ }^{2}$ Maestría en Biología, División de CBS, UAM-Iztapalapa. San Rafael Atlixco 186, Col. Vicentina. 09340. CDMX. México ${ }^{3}$ Centro Interdisciplinario de Ciencias Marinas, Instituto Politécnico Nacional. Depto. de Pesquerías y Biología Marina. Avenida Instituto Politécnico Nacional s. n., Col. Playa Palo de Santa Rita. 23096. La Paz, Baja California Sur, México ${ }^{4}$ Departamento de Hidrobiología, División de CBS, UAM-Iztapalapa. San Rafael Atlixco 186, Col. Vicentina. 09340. CDMX. México e-mail: beckygranja@gmail.com

Granja-Fernández R., P. D. Rangel-Solís, M. D. Herrero-Pérezrul and A. López-Pérez. 2016. New records of Ophiuroidea (Echinodermata) from the coast of Chiapas, Mexico. Hidrobiológica 26 (1): 143-146.

\begin{abstract}
Knowledge about ophiuroids from Chiapas, Mexico, is still limited; only Diopederma daninana was previously recorded in the state. In order to contribute to the knowledge of their diversity in the region, ophiuroids were collected in four localities of Puerto Chiapas, in different substrata and at different depths. Three species were identified: Ophiothrix (Ophiothrix) spiculata, Ophiactis savignyi, and Ophiactis simplex. 0 . simplex was the most abundant and well distributed. With these additions, we updated the checklist of ophiuroids from Chiapas to five species.
\end{abstract}

Key words: Ophiactis, Ophiothrix, Puerto Chiapas, southern Mexican Pacific.

\section{RESUMEN}

El conocimiento de los ofiuroideos de Chiapas, México es aún limitado; sólo Diopederma daniana estaba reportada para la zona. Con el objetivo de contribuir al conocimiento de la diversidad de ofiuroideos de la región, se llevaron a cabo recolectas en cuatro localidades de Puerto Chiapas, en diferentes sustratos y profundidades. Se identificaron en total tres especies: Ophiothrix (Ophiothrix) spiculata, Ophiactis savignyi y Ophiactis simplex. Ophiactis simplex fue la especie más ampliamente distribuida y más abundante. Con esta contribución, se amplía a cinco la lista de especies de ofiuroideos de Chiapas.

Palabras clave: Ophiactis, Ophiothrix, Puerto Chiapas, Pacífico sur mexicano
Chiapas is one of the states with the highest terrestrial biodiversity in Mexico (Llorente-Bousquets and Ocegueda, 2008), but still little is known about its marine biodiversity. There is consensus, however, that the marine biodiversity of Chiapas is underestimated due to its long, unexplored coast and because entire taxonomic groups remain unstudied (Aguilar-Sierra, 2011). Being the least studied state on Mexico's Pacific coast, there are few reports of marine taxa from Chiapas, most of which were published during the last decade (algae, Godínez-Ortega, 2013; crustaceans, García-Madrigal et al., 2012; polychaetes, BastidaZavala and Guevara-Cruz, 2012; mollusks, Sevilla-Hernández, 1995; fish, Penagos-García et al., 2011).

The study of echinoderms from Chiapas began in 1938 with the recording of the echinoid Clypeaster europacificus H.L. Clark, 1914 (Grant and Hertlein, 1938). During the 1940 s, the number of studies in the area increased and, for the first time, the species Luidia latiradiata (Gray, 1871) (Caso, 1944) and Mellita longifissa (Michelin, 1858) were reported in the region (Rioja, 1944; Caso, 1946). Later, Caso (1978) recorded the presence of Eucidaris thouarsii (L. Agassiz and Desor, 1846) and Mellita notabilis H.L. Clark, 1947 (Caso, 1980) along the coast of Chiapas, and then Luke (1982) discussed the echinoid Clypeaster rotundus (A. Agassiz, 1863) in the area. Several years later, Honey-Escandón et al. (2008) published the most important work on echinoderms in Chiapas in terms of the recorded species. They reported the presence of $A s$ tropyga pulvinata (Lamarck, 1816), Encope micropora L. Agassiz, 1841, Luidia tessellata Lütken, 1859, Astropecten armatus Gray, 1840, Astropecten regalis Gray, 1840, Diopederma daninana (Verrill, 1867), Heliaster microbrachius Xantus, 1860, and Trachythyone peruana (Semper, 
1868). Recently, Solís-Marín and Laguarda-Figueras (2013) provided a new recording of Holothuria (Halodeima) kefersteini (Selenka, 1867).

Thus, there are 15 species of echinoderms in Chiapas; the class Ophiuroidea is the least studied. To date, there are just two ophiuroid records from Chiapas: D. daniana collected at Puerto Madero (HoneyEscandón et al., 2008; Granja-Fernández and López-Pérez, 2012; SolísMarín and Laguarda-Figueras, 2013; Granja-Fernández et al., 2015a, $2015 b)$, and a fossil record of the family Ophiuridae, recovered from the San Juan Formation (Martín-Medrano and García-Barrera, 2006). In this article, we provide three new records of ophiuroids from the coast of Chiapas, contributing to the knowledge of the marine fauna of the region.

During May 2014, as part of a larger project regarding ophiuroid biodiversity along the Pacific coast of Mexico, we took samples at four localities in the vicinity of Puerto Chiapas, Chiapas, Mexico: Muelle Fis-

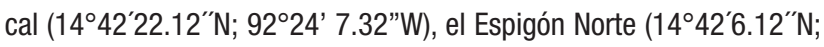

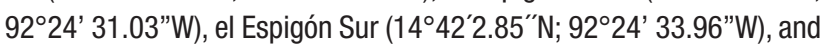
Punta del Espigón $\left(14^{\circ} 41^{\prime} 56.56^{\prime \prime} \mathrm{N}\right.$; 92 $\left.2^{\circ} 24^{\prime} 41.24^{\prime \prime W}\right)$. Chiapas is located on the southern Mexican Pacific coast. Specifically, the area of Puerto Chiapas is bounded by the Suchiate River on the east and by Puerto Arista on the west. The region is part of the Gulf of Tehuantepec, characterized by a continental shelf with soft bottoms (Lara-Lara et al., 2008). The Gulf of Tehuantepec is affected by important meteorological phenomena, known locally as the "tehuanos", i.e., northern winds that occur during the dry season in the Gulf of Mexico (Tapia-García et al., 2007; Lara-Lara et al., 2008). These winds decrease the sea surface temperature, increase salinity, and change water circulation, bringing an upwelling that increases nutrients and primary production (González-Silvera et al., 2004; Tapia-García et al., 2007; Lara-Lara et al., 2008).

We carried out collections in different substrata (rock, sediment, sponges, algae, mollusks) at depths of $1.9 \mathrm{~m}$ to $5 \mathrm{~m}$. We hand collected samples while scuba diving. The collected ophiuroids were anesthetized using cold temperatures $\left(>10^{\circ} \mathrm{C}\right)$ in order to prevent autotomy. The specimens were fixed and preserved in $70 \%$ ethanol. The specimens were identified using the works of Müller and Troschel (1842), Le Conte (1851), and Granja-Fernández et al. (2014). The valid names follow and were arranged systematically according to Smith et al. (1995) and Granja-Fernández et al. (2015a, 2015b).

A total of three species of ophiuroids were found: Ophiothrix (Ophiothrix) spiculata (Le Conte, 1851), Ophiactis savignyi (Müller and Troschel, 1842), and Ophiactis simplex (Le Conte, 1851), belonging to one order (Ophiurida), two families (Ophiactidae, Ophiothrichidae) and two genera (Ophiactis, Ophiothrix). Note that 0 . simplex was collected at all localities (except Muelle Fiscal) and was the most abundant, and was also found in a larger number of substrata (algae, sponge, rock, oyster reef). The localities el Espigón Norte and el Espigón Sur showed the highest number of species, but the former possessed the highest abundance of ophiuroids in the area under study. Rocks were the habitat with the highest number of ophiuroids, but the oyster reef showed the highest abundance of species.
Systematics:

Phylum Echinodermata Brugiére, 1791

Class Ophiuroidea Gray, 1840

Order Ophiurida Müller and Troschel, 1840

Family Ophiotrichidae Ljungman, 1867

Ophiothrix (Ophiothrix) spiculata (Le Conte, 1851)

Muelle Fiscal (11 specimens, $5 \mathrm{~m}$, sediment, 05/May/2014, $30^{\circ} \mathrm{C}$ ); el Espigón Sur (1 specimen, 3 m, rock, 05/May/2014, $30^{\circ} \mathrm{C}$ ).

Family Ophiactidae Matsumoto, 1915

Ophiactis savignyi (Müller and Troschel, 1842)

El Espigón Norte (1 specimen, 1.9 m, rock, 06/May/2014, 29 C).

Ophiactis simplex (Le Conte, 1851)

El Espigón Sur (2 specimens, $2 \mathrm{~m}$, sponge, 05/May/2014, $30{ }^{\circ} \mathrm{C}$; 1 specimen, $3 \mathrm{~m}$, sponge, 05/May/2014, $30{ }^{\circ} \mathrm{C}$ ); el Espigón Norte (5 specimens, $2 \mathrm{~m}$, sponge, 06/May/2014, $29^{\circ} \mathrm{C}$; 9 specimens, $1.9 \mathrm{~m}$, sponge, 06/May/2014, $29{ }^{\circ} \mathrm{C}$; 10 specimens, $2 \mathrm{~m}$, algae, 06/May/2014, $29^{\circ} \mathrm{C}$; 29 specimens, $1.9 \mathrm{~m}$, rock, 06/May/2014, $29^{\circ} \mathrm{C}$ ); Punta del Espigón (43 specimens, $3 \mathrm{~m}$, oyster reef, 06/May/2014, $29^{\circ} \mathrm{C}$ ).

Previous studies along the coast of Chiapas discussed the presence of $D$. daniana (Honey-Escandón et al., 2008; Granja-Fernández and López-Pérez, 2012; Solís-Marín and Laguarda-Figueras, 2013; GranjaFernández et al., 2015a, 2015b). Recently, Penagos-García et al. (2012) reported the presence of 0 . (Ophiothrix) spiculata in the Soconusco Region, Chiapas. The authors provided an illustration of the collected ophiuroid, but it turns out that the image does not correspond to the species 0. (Ophiothrix) spiculata; instead, the specimen is a member of the family Ophiocomidae and the genus Ophiocoma, since its disk is covered by granulation and the arms and arm spines are stout (GranjaFernández et al., 2014). The figure shows only the dorsal side of the specimen. However, there are some morphological characteristics suggesting that it corresponds to the species Ophiocoma alexandri Lyman, 1860: dorsal arm plates are oval hearth-shaped and wider than long; long arm spines (1.5-2 times the length of a dorsal arm plate), blunt, and more than four in number; dorsal arm plates with some plates banded (Lyman, 1860; Granja-Fernández et al., 2014).

Previously, only one report of a living ophiuroid was recorded in Chiapas (Granja-Fernández et al., 2015a, 2015b); nevertheless, considering the previous record of $D$. daniana (Honey-Escandón et al., 2008; Granja-Fernández and López-Pérez, 2012; Solís-Marín and LaguardaFigueras, 2013; Granja-Fernández et al., 2015a, 2015b), the correct assignation of the species reported in Penagos-García et al. (2012), and the three new records of this study, the total number of ophiuroid species from Chiapas is five $(D$. daniana, 0 . alexandri, 0 . savignyi, 0 . simplex, 0 . (Ophiothrix) spiculata). According to these results, Chiapas is still considered along with Michoacán and Colima (nine and 14 species, respectively) (Granja-Fernández et al. 2016), among the least biodiverse on the Pacific coast of Mexico.

Notwithstanding the increase in the number of ophiuroid species recorded in Chiapas, Granja-Fernández and López-Pérez (2012) predicted that potentially 12 species of ophiuroids inhabit the area. According to the high water dynamic and turbidity (pers. obs., Granja-Fernández, 2014), as well as the extensive sandy coast of the studied area, we 
expect to find suspension feeder species (i.e., Amphiuridae) in future studies. Moreover, once the numerous unsurveyed aquatic ecosystems in Chiapas (coastal lagoons, estuaries, mangroves, rocky shores, and sandy bottoms) are studied, it may turn out that the state has a high potential to contribute to ophiuroid diversity along the Mexican Pacific coast.

\section{ACKNOWLEDGEMENTS}

We thank Virgilio Pérez-Antonio, David Guendulain-García, and Omar Valencia-Méndez for collecting specimens. Special thanks go to Romario Jiménez and his family for collecting specimens and their kind hospitality during fieldwork. We are especially grateful to the Laboratorio de Pastos Marinos y Bentos at UAM-Iztapalapa for the facilities provided. The study was funded by CONABIO (JF047) and Hidrobiología UAMIztapalapa. We thank the referees for commenting upon and improving the manuscript.

\section{REFERENCES}

Aguilar-SIerRA, V. 2011. Recuento de la diversidad de especies de Chiapas registrada en el SNIB. En: Álvarez-Noguera, F. (Comp.). Chiapas: estudios sobre su diversidad biológica, UNAM, México. pp. 29-34.

Bastida-Zavala, R. \& C. Guevara-Cruz. 2012. Estado del conocimiento de Ios poliquetos (Annelida: Polychaeta) del Pacífico sur de México. In: Sánchez, A.J., X. Chiappa-Carrara \& R. Brito-Pérez (Eds.). Recursos Costeros del Sureste: tendencias actuales en investigación y estado del arte, CONCITEY, FOMIX, SIIDETEY, UNAM, CONACYT, ECOSUR, PROMEP, RECORECOS, UNACAR, UJAT, México. pp. 335-355.

CaSo, M. E. 1944. Estudio sobre astéridos de México. Algunas especies interesantes de astéridos litorales. Anales del Instituto de Biología, Universidad Nacional Autónoma de México 15 (1): 237-257.

CASo, M. E. 1946. Contribución al conocimiento de los equinodermos de México. I. Distribución y morfología de Mellita quinquiesperforata (Leske), M. lata Clark y M. Iongifissa Michelin. Anales del Instituto de Biología, Universidad Nacional Autónoma de México 17 (1-2): 247-259.

Caso, M. E. 1978. Los Equinoideos del Pacífico de México. Parte 1. Órdenes Cidaroidea y Aulodonta. Anales del Centro de Ciencias del Mar y Limnología, Universidad Nacional Autónoma de México, Publicación especial 1: 1-244.

CASo, M. E. 1980. Los equinoideos del Pacífico de México. Parte Tercera. Orden Clypeasteroida. Anales del Centro de Ciencias del Mar y Limnología, Universidad Nacional Autónoma de México, Publicación Especial 4: 1-252.

García-Madrigal, M.S., J. Jarquín-González \& E. Morales-Domínguez. 2012. Panorama del estado del conocimiento de los crustáceos del Pacífico Sur de México. En: Sánchez, A.J., X., Chiappa-Carrara \& R. BritoPérez. (Eds.). Recursos Costeros del Sureste: tendencias actuales en investigación y estado del arte, CONCITEY, FOMIX, SIIDETEY,
UNAM, CONACYT, ECOSUR, PROMEP, RECORECOS, UNACAR, UJAT, México. pp. 396-414.

Godínez-ORtegA, J. L. 2013. Biodiversidad de algas marinas bénticas. In: Cruz-Angón A., E. D. Melgarejo, F. Camacho-Rico \& K. C. NájeraCordero (Eds.). La biodiversidad en Chiapas: Estudio de Estado. CONABI0, Gobierno del Estado de Chiapas, México. pp. 89-95.

González-Silvera, A., E. Santamaría-del-Ángel, R. Millán-Nuñez \& H. ManzoMonRoy. 2004. Satellite observations of mesoscale eddies in the Gulfs of Tehuantepec and Papagayo (Eastern Tropical Pacific). Deep-Sea Research II 51: 587-600.

Granja-Fernández, M. R. \& R. A. López-Pérez. 2012. Biodiversidad de ofiuroideos (Echinodermata: Ophiuroidea) de Oaxaca y Chiapas. En: Sánchez, A. J., X. Chiappa-Carrara \& R. Brito-Pérez (Eds.). Recursos Costeros del Sureste: tendencias actuales en investigación y estado del arte, CONCITEY, FOMIX, SIIDETEY, UNAM, CONACYT, ECOSUR, PROMEP, RECORECOS, UNACAR, UJAT, México. pp. 357-370.

Granja-Fernández, R., M. D. Herrero-Pérezrul, R. A. López-Pérez, L. Hernández, F. A. Rodríguez-Zaragoza, R. W. Jones \& R. Pineda-López. 2014. Ophiuroidea (Echinodermata) from coral reefs in the Mexican Pacific. ZooKeys 406: 101-145.

Granja-Fernández R., F. A. Solís-Marín, F. Benitez-Villalobos, M. D. HerreroPérezrul \& A. López-Pérez. 2015a. Checklist of echinoderms (Echinodermata) from the Southern Mexican Pacific: a historical review. Revista de Biología Tropical 63 (2): 87-114.

Granja-Fernández R., M. D. Herrero-Pérezrul, R. A. López-Pérez, A. Hernández-Morales \& P. D. Rangel-Solís. 2015b. A literature review of the Ophiuroidea (Echinodermata) from the Pacific coast of Mexico. Revista de Biología Tropical 63 (2): 37-47.

Granja-Fernández R., A. P. Rodríguez-Troncoso, M. D. Herrero-Pérezrul, R. C. Sotelo-Casas, J. R. Flores-Ortega, E. Godínez-Dominguez, P. SalazarSilva, L. C. Alarcón-Ortega, A. Cazares-Salazar \& A. L. Cupul-Magaña. 2016. Ophiuroidea (Echinodermata) from the Central Mexican Pacific: an updated checklist including new distribution records. Marine Biodiversity. DOI 10.1007/s12526-016-0459-4

Grant, U. S. \& L. G. Herteein. 1938. The West American Cenozoic Echinoidea. Publications of the University at Los Angeles in Mathematical and Physical Sciences 2 (6): 1-225.

Honey-Escandón, M., F. A. Solís-Marín \& A. Laguarda-Figueras. 2008. Equinodermos (Echinodermata) del Pacífico Mexicano. Revista de Biología Tropical 56 (3): 57-73.

Lara-Lara, J. R., V. Arenas-Fuentes, M. D. C. Bazán-Guzmán, M. C. GarcíaAbad, V. M. Diaz-Castañeada, E. Escobar-Briones, G. Gaxiola-Castro, E. G. Robles-Jarero, R. Sosa-Ávalos, L. A. Soto-González, M. Tapia-García \& J. E. VAldez-Holguín. 2008. Los ecosistemas marinos. In: Sarukhán J. (Coord.). Capital Natural de México. Vol I. Conocimiento actual de la biodiversidad. CONABI0, México. pp. 135-159.

Le Conte, J. L. 1851. Zoological Notes. Proceedings of the Academy of Natural Sciences of Philadelphia 5: 316-319. 
Llorente-Bousquets, J. \& S. Ocegueda. 2008. Estado del conocimiento de la biota. En: Soberón, J., G. Halfter, \& J. Llorente-Bousquets (Comps.). Capital Natural de México. Vol. l: Conocimiento actual de la Biodiversidad. CONABI0, México. pp. 282-322.

LUKE, S. R. 1982. Catalog of benthic invertebrate collections, Echinodermata. Scripps Institution of Oceanography References Series, no. 82-5, University of California, California. $71 \mathrm{p}$.

LYMAN, T. 1860. Descriptions of new Ophiuridae, belonging to the Smithsonian Institution and to the Museum of Comparative Zoology at Cambridge. Proceedings of the Boston Society of Natural History 7: 193-204, 252-262.

Martín-Medrano, L. \& P. García-Barrera. 2006. Fossil ophiuroids of Mexico. In: Vega F., T. G. Nyborg, M. C. Prrilliat, M. Montellano-Ballesteros, S. R. S. Cevallos-Ferriz \& S. A. Quiroz-Barroso (Eds.). Studies on Mexican Paleontology. Springer, Netherlands. pp. 115-131.

MülleR, J. \& F. H. Troschel. 1842. System der Asteriden. Friedrich Vieweg und Sohn, Braunschweig, Germany. 134 p.

Penagos-García, F. E., M. Tapia-García, E. Espinoza-Medinilla \& C. U. del Carpio-Penagos. 2011. Ictiofauna de la plataforma continental de la Región Soconusco, Chiapas, México. Lacandonia 5 (2): 103-126.

Penagos-García, F. E., 0. Lam-Gordillo, G. Rivera-Velázquez, M. Tapia-García \& G. JuÁreZ-Hernández. 2012. Equinodermos (Echinodermata) de la línea de costa y de la plataforma continental de la Región Soconusco, Chiapas, México. Lacandonia 6 (1): 55-63.
RıoJA, E. 1944. Estudios carcinológicos XVI. Observaciones sobre algunas especies de cangrejos del género Dissodactylus Smith (Braquiros pinnoteridos) de las costas mexicanas del Pacífico. Anales del Instituto de Biología, Universidad Nacional Autónoma de México 15: 147-160.

Sevilla-Hernández, M. L. 1995. Moluscos de la franja costera de Chiapas. IPN, México. 152 p.

Smith, A. B., G. L. J. Paterson \& B. Lafay. 1995. Ophiuroid phylogeny and higher taxonomy: morphological, molecular and palaeontological perspectives. Zoological Journal of the Linnean Society 114: 213-243.

Solis-Marín, F. A. \& A. Laguarda-Figueras. 2013. Equinodermos (Echinodermata). In: Cruz-Angón, A., E. D. Melgarejo, F. Camacho-Rico \& K. C. Nájera-Cordero (Eds.). La Biodiversidad en Chiapas: Estudio de Estado. CONABIO, Gobierno del Estado de Chiapas, México. pp. 181-185.

Tapia-García, M., M. C. García-Abad, A. Carranza-Edwards \& F. Vásquez-GutiéRREZ. 2007. Environmental characterization of the continental shelf of the Gulf of Tehuantepec, Mexico. Geofísica Internacional 46 (4): 249-260.

Recibido: 14 octubre de 2014.

Aceptado: 07 julio de 2015. 